\title{
Sacred Space and Torah Shrines in Late Antique Synagogues
}

\section{Tervahauta-Helin, Ulla Kristiina}

Vandenhoeck \& Ruprecht

2020

Tervahauta-Helin , U K 2020 , Sacred Space and Torah Shrines in Late Antique Synagogues . in R Bonnie, R Hakola \& U Tervahauta (eds), Synagogue in Ancient Palestine : Current Issues and Emerging Trends. Forschungen zur Religion und Litteratur des Alten und Neuen Testaments, no. 279 , Vandenhoeck \& Ruprecht, Göttingen, pp. 311-336 . https://doi.org/10.13109/9783666522147.311

http://hdl.handle.net/10138/336350

https://doi.org/10.13109/9783666522147.311

unspecified

acceptedVersion

Downloaded from Helda, University of Helsinki institutional repository.

This is an electronic reprint of the original article.

This reprint may differ from the original in pagination and typographic detail.

Please cite the original version. 


\section{Sacred Space and Torah Shrines in Late Antique Synagogues}

\section{Ulla Tervahauta}

In this article I discuss synagogue architecture, the emerging centrality of Torah shrines, and growth in their perceived holiness in light of and as parallel with how Christianity and Christian sacred architecture evolved. ${ }^{1}$ I build on the work of scholars who have studied synagogues as well as those who have studied churches and sacred space in Late Antiquity.

In both Jewish and Christian contexts sacred spaces and buildings become more visible than previously from the fourth century onward, and space is arranged in new ways. Different answers to how and why Torah shrines first emerge in synagogues, what is expressed through their prominence, and what their role in worship was have been suggested. Proposed explanations point to both internal and external causes: changes in Jewish liturgy and worship, the emergence of imperial Christianity, and the Jewish response to Christianity. In this article, I approach the development of Torah shrines in late antique synagogues as a phenomenon simultaneous with the development of Christian churches and ecclesiastical architecture, altars in particular. I suggest that these developments are in many ways parallel and indicate increased complexity and hierarchical arrangements in worship and that arrangement of space is not merely an expression of how the sacred is conceptualized, but also ties in with communal hierarchies.

Remains of Torah shrines and arks are virtually lost, but there are traces of niches, platforms, and apses in ancient synagogues that are interpreted as marking the place of the Torah shrine of the synagogue in question. ${ }^{2}$ Here a note on terminology is apropos. By Torah ark (aron) I mean wooden chests that contained the Scripture scrolls; these have not survived. By Torah shrine I refer to the particular architectural structure that was intended for storing the Scripture scrolls and the chest where they were held: a Torah shrine could be a niche in a wall or an aedicula shrine, sometimes located in an apse. ${ }^{3}$ Archeological remains of Torah shrines

\footnotetext{
${ }^{1}$ I thank Rick Bonnie, Raimo Hakola, Kirsi Valkama, and Jürgen Zangenberg who have all read and commented on some version of this work. Their comments have greatly improved the text, while any remaining weaknesses or mistakes are my own.

${ }^{2}$ Rachel Hachlili, Ancient Synagogues-Archaeology and Art: New Discoveries and Current Research, HdO 105 (Leiden: Brill, 2013), 197-98; Lee I. Levine, The Ancient Synagogue: The First Thousand Years (New Haven: Yale University Press, 2000), 220, 327-28.

${ }^{3}$ Chad Spigel, Ancient Synagogue Seating Capacities: Methodology, Analysis and Limits, TSAJ 149 (Tübingen: Mohr Siebeck 2012), 44-45; Eric Meyers, "The Torah Shrine in the Ancient Synagogue: Another Look at the
} 
are found in post-Constantinian synagogues, and the existing evidence (remains of platforms) indicates that Torah shrines become larger and more prominent over the course of the Byzantine era (fourth to seventh centuries in Palestine).

The first part of this article discusses Torah shrines, so-called façade motifs in mosaics, and archaeological remains of the Torah shrines. The focus is on the significance of the increased size of Torah shrines over the period of the fourth to the seventh century. Previous scholarly discussions and interpretations regarding Torah shrines and the holiness of synagogues will be presented. The historical context will then be briefly mapped. Finally, Christian holy spaces are brought into the discussion: the aim is to enrich readings of Jewish sacred spaces by considering how Christian concepts of sacred space evolved in Late Antiquity.

\section{Torah shrines: images and remains from Late Antiquity}

We begin with a seemingly simple question: what did a Torah shrine look like? Different kinds of platforms, apses and niches indicate places in ancient synagogues where the Torah shrine stood, but no Torah shrine has been preserved intact. Torah arks and scrolls have not survived over the centuries.

Before we proceed to the platform remains found in many synagogues, it is worth visiting the so-called façade motifs in ancient synagogue mosaic floors. Several synagogues from late antique Palestine have colorful and richly decorated mosaic floors with rich visual and architectural programs that often contain a depiction of a building façade. These synagogues include Sepphoris, Beth Alpha, Hammath Tiberias, Susiya, and Na'aran. One of the finest examples is in the synagogue of Hammath Tiberias: the panel above its zodiac mosaic portrays a façade flanked by two very large menorahs. The façade stands on a low platform that has two wide steps. On either side of the steps stands a plinth used as a column base that is about the same height as the steps leading onto the platform, and on each column base stands a column with an Ionic capital. The two columns support a roof and a triangular pediment that has a decoration on its upper edge and a conch in the middle. A pair of wooden doors fill the structure: in front of the doors hangs a curtain tied in a knot. Two different types of stone are

Evidence," JSQ 4 (1997): 303-38; David Milson, Art and Architecture of the Synagogue in Late Antique Palestine: In the Shadow of the Church, AJEC 65 (Leiden: Brill, 2007), 119. As Meyers and Spigel note, the Torah shrine and ark housed scrolls that contained Hebrew Scriptures. What texts exactly were in question would have varied between different communities. I refrain from using the term bema for a raised platform on which the Torah shrine stood: some synagogues had a speaker's platform, a bema, for reading the Scriptures and delivering sermons. See Levine, Ancient Synagogue, 319-23. 
used in this structure; the column bases and the platform appear to be made of black stone, perhaps basalt, while the columns and the roof are light in color, perhaps indicating limestone. The stone blocks under the two menorahs seem to be made of black stone.

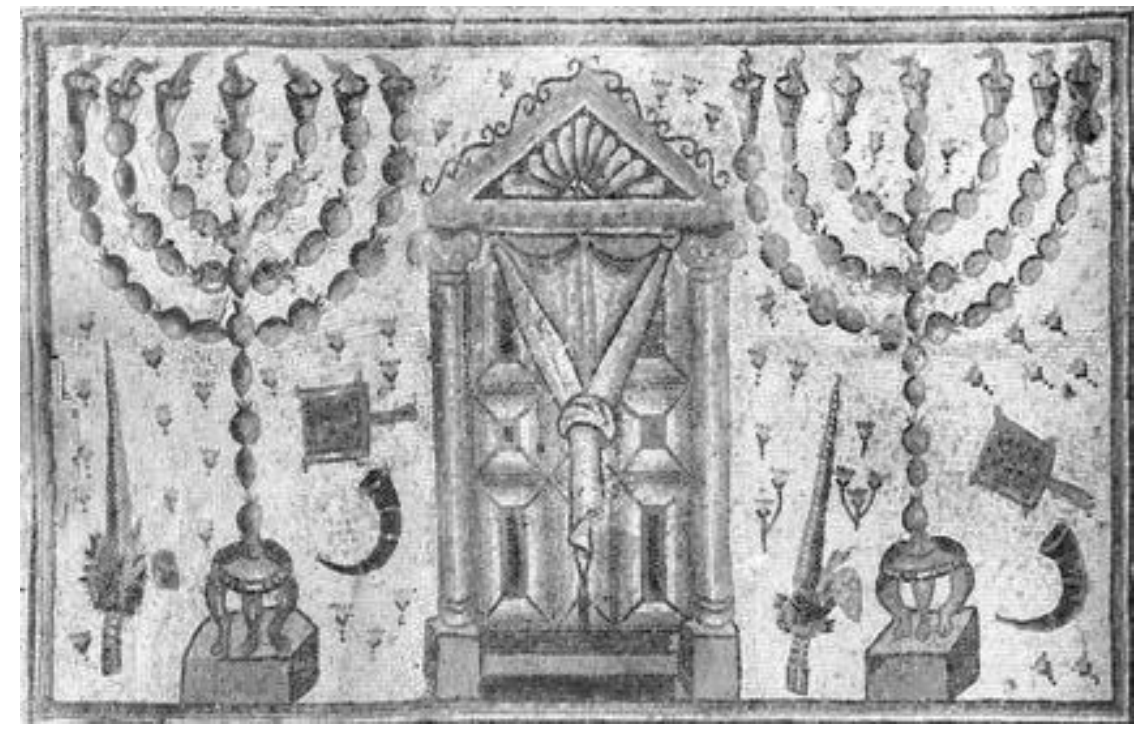

Figure 1. A façade with a menorah on both sides and with ritual objects; detail from the mosaic carpet in the Hammath Tiberias IIa synagogue (photo: Gilead Peli / The Bornblum Eretz Israel Website).

The excavator who dated the mosaic to the third to the fourth century CE interpreted it as depicting a Torah shrine with the ark within. ${ }^{4}$ There is a resemblance to platform remains found in ancient synagogues, suggesting that this and other such mosaic images may depict a Torah shrine. A mosaic carpet such as the one at Hammath Tiberias decorates the floor and educates those viewing it with themes taken from worship and the Scriptures. It also directs the viewer's attention towards the Torah ark. ${ }^{5}$ In that sense, there exists a connection between the ark and shrine and the image on the floor. Yet interpretation of a mosaic such as Hammath Tiberias is not, as the reader will know, straightforward, but rather raises questions. Other connotations are detectable in the Hammath Tiberias mosaic (and other mosaics with façade motifs): the objects depicted around the façade and the two menorahs flanking it can be read as referring to the Jerusalem temple and worship. This is why different readings have been suggested: while Dothan and many others argue that the façade depicts the Torah shrine/ark, ${ }^{6}$ others read façade

\footnotetext{
4 Moshe Dothan, Hammath Tiberias, Vol. 1: Early Synagogues and the Hellenistic and Roman Remains (Jerusalem: Israel Exploration Society, 1983), 33-37.

${ }^{5}$ See Zeev Weiss's article in this volume.

${ }^{6}$ Steven Fine, This Holy Place: On the Sanctity of the Synagogue during the Greco-Roman Period, Christianity and Judaism in Antiquity 11 (Notre Dame, IN: University of Notre Dame Press, 1997), 112-14, 117-22; Hachlili,
} 
motifs as representations of the Jerusalem temple, or the future temple, signifying the "the messianic longing for the rebuilding of the land and the Temple."

Indeed, mosaics are open to different readings, as has also been argued previously. ${ }^{8}$ I find Joan Branham's position helpful. She has suggested that synagogues of the era can be understood to negotiate "between two opposing forces: the assertion of its own legitimacy and integrity ... and acknowledgment of its perpetual bond and deference to the Jerusalem temple tradition." The temple was lost yet evoked within synagogue space. ${ }^{9}$ Branham's reading indicates a community that found its identity condensed in the Torah/Scriptures, preserved memories of the past, built its identity in the present, and looked to the future. These aspects are contained in façade mosaics, and consequentially they can refer to the temple, portray or point to the Torah shrine, and refer to what is most sacred and hoped for. Similarly, Bianca Kühnel argues that it is the continuity and connection between the tabernacle, the temple, Torah

Ancient Synagogues, 286-91; Orit Peleg-Barkat, "Interpreting the Uninterpreted: Art as a Means of Expressing Identity in Early Roman Judea," in Jewish Art in Its Late Ancient Context, ed. Uzi Leibner and Catherine Hezser, TSAJ 163 (Tübingen: Mohr Siebeck, 2016), 40 n. 52; Michael Avi-Yonah, "Synagogue Architecture in the Classical Period," in Jewish Art: An Illustrated History, ed. Cecil Roth (London: W. H. Allen, 1961), 185-86; Rachel Wishnitzer-Bernstein, "Jewish Pictorial Art in the Classical Period," in Jewish Art: An Illustrated History, ed. Cecil Roth (London: W. H. Allen, 1961), 213, 215-18, 221-22.

${ }^{7}$ Peleg-Barkat, "Interpreting the Uninterpreted," $40-41$ and 40 n. 52. Cecil Roth suggested reading mosaics as depicting the temple, or a synagogue Torah shrine, depending on whether the doors are open or closed. When open and scrolls seen within, or with two candelabra flanking the façade, the context in his view would be that of a synagogue rather than the temple. Cecil Roth, "Jewish Antecedents of Christian Art," Journal of the Warburg and Courtauld Institutes 16 (1953): 27-28. See also Lidia Chakovskaya's discussion on the Beth Alpha mosaic in this volume.

${ }^{8}$ Zeev Weiss, "Decorating the Sacred Realm: Biblical Depictions in Synagogues and Churches of Ancient Palestine," in Jewish Art in Its Late Antique Context, ed. Uzi Leibner and Catherine Hezser, TSAJ 163 (Tübingen: Mohr Siebeck, 2016), 124; Zeev Weiss, "The Sepphoris synagogue mosaic and the role of Talmudic literature in its iconographical study," in From Dura to Sepphoris: Studies in Jewish Art in Late Antiquity, ed. Lee I. Levine and Zeev Weiss, JRASup 40 (Portsmouth, RI: JRA, 2000); Milson, Art and Architecture, 106-40; Roth, "Jewish Antecedents," 24-44; Peleg-Barkat, "Interpreting the Uninterpreted," 40. In text studies, the shift from authorial intention to the reception and readings given by different audiences sheds light on multiple interpretative situations and contexts: images, like texts, can be received in divergent ways. Roland Deines, "God's Revelation Through Torah, Creation, and History," in Jewish Art in Its Late Antique Context, ed. Uzi Leibner and Catherine Hezser, TSAJ 163 (Tübingen: Mohr Siebeck, 2016), 155-57.

9 Joan Branham, "Vicarious Sacrality: Temple Space in Ancient Synagogues," in Ancient Synagogues: Historical Analysis and Archaeological Discovery, ed. Dan Urman and Paul V.M. Flesher, StPB 47 (Leiden: Brill, 1995), 2:319-45; quotation on p. 320 . 
ark, and the future temple that are emphasized by these mosaics that obliterate any temporal boundaries. $^{10}$

Ultimately, we may not know that the façade in this mosaic, or other mosaics, portrays the Torah shrine, but neither do we know that it does not. I suggest that while an outward resemblance to a Torah shrine is recognizable, any interpretation of such an image must remain multivalent and ambiguous. Yet mosaic evidence is important for our discussion, as mosaics indicate meanings attached to the Torah shrine and suggest connections that were to be drawn. A mosaic may not, in an unambiguous way, portray a Torah shrine, but it may, even so, still indicate how a Torah shrine looked like despite mingling the Torah shrine with the temple. An aedicula-type shrine would accentuate the connection of the Torah shrine and the memory of the temple, and recall this connection in the synagogue space. A similar phenomenon can be found in the Christian context: the Anastasis shrine in the Holy Sepulchre was not only visited by Byzantine Christian pilgrims, but models and images of it were reproduced in Christian churches. ${ }^{11}$ One of many is visible in a mosaic, today in the collection of the National Museum of Denmark. The unprovenanced mosaic possibly comes from Syria or elsewhere in the Levant, appears Byzantine in its style, and portrays a rounded shrine that resembles the Anastasis in Jerusalem (Fig. 2). ${ }^{12}$

${ }^{10}$ Bianca Kühnel, "The Synagogue Floor Mosaic in Sepphoris: Between Paganism and Christianity," in From Dura to Sepphoris: Studies in Jewish Art in Late Antiquity, ed. Lee I. Levine and Zeev Weiss, JRASup 40 (Portsmouth, RI: JRA, 2000), 34.

${ }^{11}$ Jonathan Z. Smith, To Take Place: Toward Theory in Ritual (Chicago: The University of Chicago Press, 1987), 86-87. Robert Ousterhout has pointed to the resemblance between façades and aediculae in Jewish art and representations of the Holy Sepulchre in Christian art. He suggests that not only Christian imagery but the tomb aedicula itself may have been borrowed from Jewish art. Robert Ousterhout, "The Temple, the Sepulchre, and the Martyrion of the Savior," Gesta 29 (1990): 44-53. On copies of the Holy Sepulchre, see, e.g., Richard Krautheimer, "Iconography of Medieval Architecture," JWCI 5 (1942): 1-33, Laura D. Gelfand, "Sense and Simulacra: Manipulation of the sense in medieval 'copies' of Jerusalem," Postmedieval: a journal of medieval cultural studies 3 (2012): 407-22, and Robin Griffth-Jones, "Public, Private and Political Devotion: Re-presenting the Sepulchre," in Tomb and Temple: Re-imagining the Sacred Buildings of Jerusalem, ed. Robin Griffth-Jones and Eric Fernie (Woodbridge: The Boydell Press, 2018), 17-47, and other articles in the volume.

${ }^{12}$ The provenance of the mosaic is unknown. The National Museum of Denmark informed me that it was obtained from the international art market between 1972 and 1975 (e-mail correspondence). According to Trolle and Pentz, the mosaic was donated to the National Museum of Denmark by the New Carlsberg Foundation in 1975. Stephen Trolle and Peter Pentz, "Den hellige grav i Jerusalem," Nationalmuseets Arbejdsmark (1983): 97-112. 


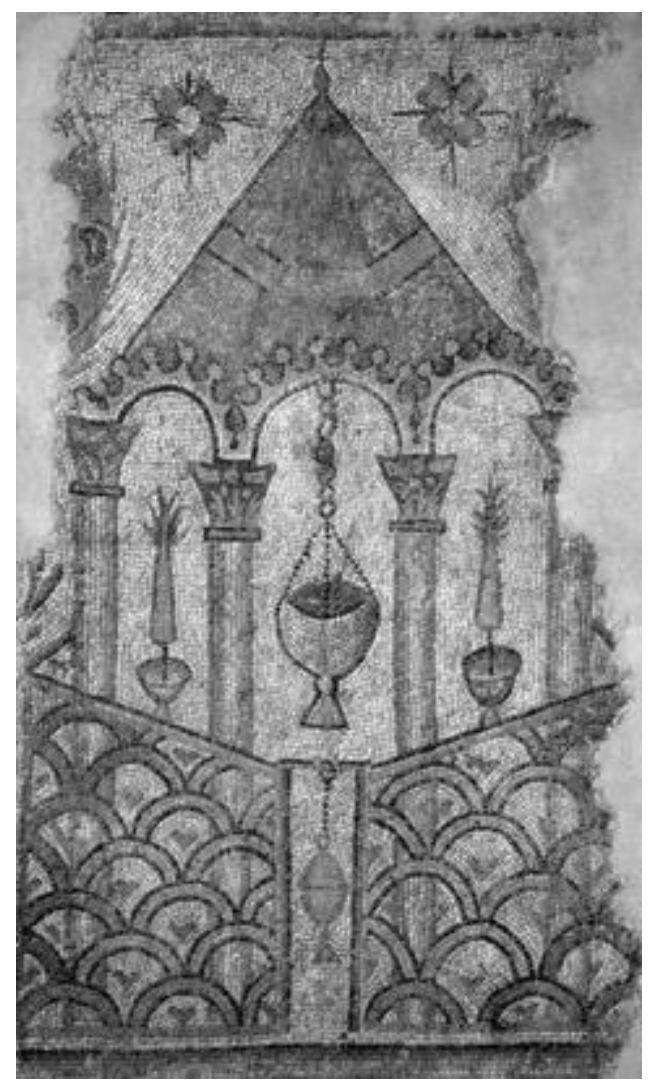

Figure 2. An unprovenanced mosaic section, possibly from Syria, now in the Antiquities collection of the National Museum of Denmark, inv. no. 15137. The mosaic depicts a rounded structure with a roof supported by columns. The hanging lamp in the middle and the incense-burners suggest a liturgical content. The structure appears to be a shrine and recalls the Anastasis in Jerusalem. (Photo: Lennart

Larsen. Published with permission of the National Museum of Denmark.)

Archaeological remains interpreted as actual Torah shrines have been divided into three categories. The first is a raised platform on which stood an aedicula shrine: such remains have been found, for example, at Gush Halav, Meiron, Hammath Tiberias, Qasrin and Umm elQanatir. Synagogues in Capernaum, Meroth, Nabratein, and Chorazin had two aediculae. Second, a niche built into an interior wall, for instance at Arbel, is also taken to indicate the place of the Torah ark, and finally, in some ancient synagogues an apse was built onto the interior wall. These synagogues include Beth Alpha, Beit Shean, Hammath Tiberias IIa and 
Hammath-Gader. Apses are found in synagogues dated to the late fifth to the early sixth century CE. ${ }^{13}$ It is safe to assume that this architectural form was inspired by church architecture. ${ }^{14}$ Platforms, apses, and other indications of Torah shrines began to emerge in the Constantinian era and they became more prominent over the centuries. A difference exists in comparison with the earliest synagogues. They seem to have been predominantly meeting places and places for the study of the Torah and the Scriptures. ${ }^{15}$ Synagogues in Gamla or Magdala, for example, had benches along all of their interior walls, emphasizing their communal function. These benches are the most distinctive element of their interiors and seem to reflect their role as meeting places. ${ }^{16}$ Remains of platforms, apses, and niches of different designs emerge first during Late Antiquity and are found against the Jerusalem-facing wall. This enhances the connection between the Torah shrine and the temple. ${ }^{17}$ These remains are focal or prominent features of the interior and are interpreted as marking the place of the synagogue's Torah shrine. ${ }^{18}$ These material expressions of worship and Jewish liturgy in Late Antiquity indicate that synagogues had become places of prayer and worship in a more pronounced way than before.

A few examples are appropriate here. In Galilee and Golan, raised platforms on which the Torah shrines probably stood have been found, for example, at Capernaum, Chorazin,

\footnotetext{
${ }^{13}$ Hachlili, Ancient Synagogues, 164. Avi-Yonah sought clarity by organizing the evidence chronologically; Michael Avi-Yonah, "Synagogue Architecture.” I follow Levine and other scholars who refrain from attempting to seek chronologically different types of synagogues. Levine, Ancient Synagogue, 296-99. See also Jodi Magness's article in this collection.

${ }^{14}$ Meyers, "The Torah Shrine," 321.

${ }^{15}$ Levine, Ancient Synagogue, 219-20.

${ }^{16}$ Levine, Ancient Synagogue, 327-28; Hachlili, Ancient Synagogues, 26-43.

17 On orientation, see Levine, Ancient Synagogue, 302-6; Hachlili, Ancient Synagogues, 161, 163. Aligning synagogues towards Jerusalem is expressed in Rabbinic literature: t. Meg. 3:21-23. Fine reads this as conceptualizing the synagogue in terms of the temple. Fine, This Holy Place, 49, 51-53. Rachel Hachlili is of the opinion that nearly every synagogue from the late second century CE onward contains architectural features that can be interpreted as a Torah shrine. Other scholars have been more cautious. Hachlili, Ancient Synagogues, 163 and nn. 3-4.

${ }^{18}$ Hachlili, Ancient Synagogues, 47. Other considerable changes took place between the Second Temple period and Late Antiquity; probably the most notable is the emergence of figurative art including depiction of humans and animals. These fall outside the scope of the present article. Peleg-Barkat, "Interpreting the Uninterpreted," 27-48 and Lee I. Levine, "Why Did Jewish Art Flourish in Late Antiquity," in Jewish Art in Its Late Ancient Context, ed. Uzi Leibner and Catherine Hezser, TSAJ 163 (Tübingen: Mohr Siebeck, 2016), 49-74 discuss the characteristics of Jewish art in the respective eras.
} 
Meroth and Umm el-Qanatir. ${ }^{19}$ Some of the more recent evidence comes from Horvat Kur. ${ }^{20}$ The large and relatively well-preserved platform remains at Horvat Kur yield new material for the study of synagogues in the Byzantine era. The building itself is of a broadhouse type, orientated towards the south, with one entrance in the west wall and another, narrower entrance in the south wall. The platform and the south entrance take the central place of the south wall, and the platform dominates the interior. The synagogue underwent several changes over the centuries. The platform, an extensive, square-shaped structure built of limestone ashlars, can be dated to the first phase of the broadhouse synagogue, from the first half of the fifth century until ca. $600 .{ }^{21}$ Compared with the size of the building's interior, its proportions are large: its length (north-south) is approximately one third of the building's length and it was a relatively high structure, more than two courses of large ashlars, or perhaps $60-70$ centimeters. ${ }^{22}$ The

${ }^{19}$ For synagogues in Galilee and Golan, see Hachlili, Ancient Synagogues, 59-116. Images can be viewed on Kinneret College, “The Bornblum Eretz Israel Synagogues Website” (2016): http://synagogues.kinneret.ac.il.

${ }^{20}$ The platform was excavated in 2010-2013 and 2016-2017. My familiarity with the synagogue of Horvat Kur stems from my participation in Horvat Kur excavations in 2011-2016 and 2019 and my study of the Horvat Kur material. I am indebted to my Horvat Kur colleagues, especially Jürgen Zangenberg and Annalize Rheeder, for discussions on the platform and the entire building. For publications of Horvat Kur material, see Jürgen K. Zangenberg et al., "The Kinneret Regional Project excavations of a Byzantine synagogue at Horvat Kur, Galilee, 2010-2013: a preliminary report," HBAI 2 (2013): 557-76; Jürgen K. Zangenberg et al., "Horbat Kur, Kinneret Regional Project - 2012, 2013," Hadashot Arkheologiyot-Excavations and Surveys in Israel 128 (2016), http://www.hadashot-esi.org.il/Report_Detail_Eng.aspx?id=24903; Jürgen K. Zangenberg, “A Basalt Stone Table from the Byzantine Synagogue at Horvat Kur, Galilee: Publication and Preliminary Interpretation," in Arise, Walk Through the Land: Studies in the Archaeology and History of the Land of Israel in Memory of Yizhar Hirschfeld on the Tenth Anniversary of his Demise, ed. Joseph Patrich, Orit Peleg-Barkat, and Erez Ben-Yosef (Jerusalem: Israel Exploration Society, 2016), 61-78; Jürgen K. Zangenberg, "Performing the Sacred in a Community Building: Observations from the 2010-2015 Kinneret Regional Project Excavations in the Byzantine Synagogue of Horvat Kur (Galilee)," in Spaces in Late Antiquity: Cultural, Theological and Archaeological Perspectives, ed. Juliette Day et al. (London: Routledge, 2016), 166-89; Jürgen K. Zangenberg, "Will the Real Women Please Sit Down: Interior Space, Seating Arrangements, and Female Presence in the Byzantine Synagogue of Horvat Kur in Galilee" in Gender and Social Norms in Ancient Israel, Early Judaism and Christianity: Texts and Material Culture in Eastern Mediterranean Cultures, ed. Michael Bauks, Katherina Galor, and Judith Hartenstein, JAJSup 28 (Göttingen: Vandenhoeck \& Ruprecht, 2019), 91-118.

${ }^{21}$ An earlier synagogue existed before the broadhouse synagogue. At this point the synagogue was smaller, square shaped, and had a mosaic floor. It was enlarged into a broadhouse synagogue around 420, or the first half of the fifth century. After ca. 600, new changes were made, and the platform was also changed. It appears to have been filled and lowered. I am indebted to Jürgen Zangenberg for discussion here.

${ }^{22}$ Zangenberg, "Performing the Sacred," 166-89. 
platform was carefully built and at that point the most prominent feature in the building's interior. Only scant remains exist for what stood on the platform, but architectural fragments found on the site indicate that there were probably columns, possibly with an arch or some type of roof. ${ }^{23}$ It was ascended by a staircase on its north side, the side facing the congregation. Under the platform was an interior space that was accessed through a large entrance on the east side of the platform. Work on the Horvat Kur synagogue is on-going at the time of writing, but it is clear that the platform demonstrates its importance within the building and to the community that gathered in it. ${ }^{24}$

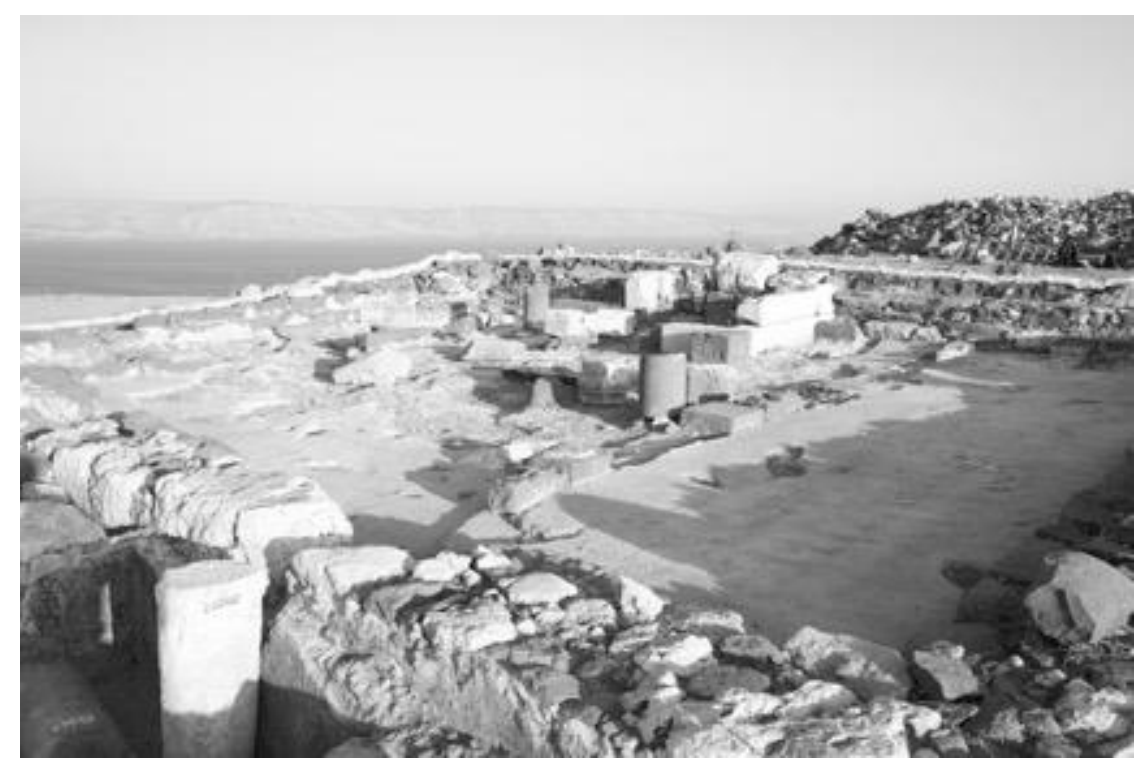

Figure 3. The synagogue of Horvat Kur after the 2017 excavation season. The platform remains abutting the south wall, here seen from the northwest corner, indicate the prominence of the Torah shrine in the building's interior (photo: Jaakko Haapanen/Kinneret Regional Project).

The Horvat Kur synagogue is a highly interesting representative of late antique synagogues and their diversity. The building and also the platform differ from synagogues that were closest to it, that is, synagogues in Capernaum, Chorazin and Huqoq. In the Capernaum synagogue, an aedicula platform stood on either side of its south entrance. ${ }^{25}$ The size and architecture of the limestone building in Capernaum is an obvious indication of wealth that may have derived to some extent at least - from Christian pilgrims who visited Capernaum. In that sense the synagogue may reflect the role and wealth of Capernaum as a major Christian pilgrimage

\footnotetext{
${ }^{23}$ Zangenberg, "Performing the Sacred," 185.

${ }^{24}$ Zangenberg, "Performing the Sacred," 183-89.

${ }^{25}$ Hachlili, Ancient Synagogues, 57, 61-63.
} 
center. ${ }^{26}$ Evidence from Chorazin also indicates that there were two platforms, one on each side of the southern entrance. ${ }^{27}$ Some resemblance to the Horvat Kur platform can be seen in the synagogue of Meroth. It had two platforms, and it is the western platform that provides some points of comparison: it was the larger of the two (yet smaller than the Horvat Kur platform), and relatively high, three or four courses of stones and over one meter in height. Like the Horvat Kur platform, the Meroth platform was built of limestone and decorated with pilasters on two sides. Both platforms, flanking the south entrance, were original to the synagogue, built in the first half of the fifth century, but the western platform with pilasters was rebuilt over an older one and enlarged in the early sixth century when the southern entrances were also blocked off. ${ }^{28}$ This is interesting and it can be hypothesized that behind such changes could be a wish to accentuate the western platform.

An even closer resemblance to the Horvat Kur platform has been detected at Umm elQanatir on the Golan. ${ }^{29}$ The synagogue at Umm el-Qanatir, built entirely of basalt that is readily available on the Golan, had a high platform with a decorated cornice. An aedicula with four colonnettes and a Syrian gable has been reconstructed on the platform. It has a narrow staircase on its north side, facing the main hall, to allow ascent, ${ }^{30}$ and an interior space with a small side

\footnotetext{
${ }^{26}$ Joan E. Taylor, Christians and the Holy Places: The Myth of Jewish-Christian Origins (Oxford: Clarendon, 1993), 228-29 (discussing Nazareth), 291-93 (Capernaum), has suggested that Christian pilgrims brought in economic resources that could have contributed to synagogue building; she also notes that the economic situation of Byzantine Palestine was, generally speaking, good. Revenues from pilgrimage would have added to the general wealth. Doron Bar is reluctant to explain economic affluence in late antique/Byzantine Palestine through Christian influence. Doron Bar, "Population, Settlement and Economy in Late Roman and Byzantine Palestine (70-641 AD)," BSOAS 67 (2004): 307-20. On pilgrimage, see Mordechai Aviam and Jacob Ashkenazi, "Late Antique Pilgrim Monasteries in Galilean Loca Sancta," LASBF 64 (2014): 566-68. See also Raimo Hakola's article in this volume, and Raimo Hakola, "Galilean Jews and Christians in Context: Spaces Shared and Contested in the Eastern Galilee in Late Antiquity," in Spaces in Late Antiquity: Cultural, Theological and Archaeological Perspectives, ed. Juliette Day et al. (London: Routledge, 2016), 160-61.

${ }^{27}$ Hachlili, Ancient Synagogues, 69.

${ }^{28}$ Hachlili, Ancient Synagogues, 170, 173-76. Milson considers the chronological evidence secure: Milson, Art and Architecture, 80-82, 181, and 434-39.

${ }^{29}$ Zangenberg, "Performing the Sacred," 185.

${ }^{30}$ Yehoshua Dray, Ilana Gonen, and Chaim Ben David, "The Synagogue of Umm el-Qanatir: Preliminary Report," IEJ 67 (2017): 209-31. For photos, see also http://www.yeshuat.com/. Methodological difficulties in the context of Golan archaeology are discussed by Claudine M. Dauphin and Jeremy J. Schonfield, "Settlements of the Roman and Byzantine Periods on the Golan Heights: Preliminary Report on Three Seasons of Survey (1979-1981)," IEJ 33 (1983): 189-206.
} 
entrance on the western side. Although the Umm el-Qanatir platform provides an obvious point for comparison, its dating remains uncertain. ${ }^{31}$ The platform at Horvat Kur, in light of current knowledge, can be dated to the early fifth century. It is possible that it is the earlier of the two, if the synagogue in Umm el-Qanatir was built later in the fifth century.

These few examples from some of the synagogues in Galilee and Golan are only a small selection of the variety that the evidence indicates regarding remains of structures that in all likelihood housed Torah arks. ${ }^{32}$ Different explanations have been proposed to explain changes in synagogue worship that also become evident in the way Torah shrines developed in Late Antiquity. Some scholars see the destruction of the Jerusalem temple as foundational for the changes. After the temple cult ceased to exist, worship and communal prayer were taken into synagogues and local communities, and these new functions then found their tangible expressions in synagogue architecture. ${ }^{33}$

While it is true that the destruction of the Second Temple was a major, dramatic event with irrevocable consequences, scholars assess its significance differently. Many do not see the loss of the temple in $70 \mathrm{CE}$ as the (sole) factor explaining the development of various Jewish institutions and practices in the following centuries. ${ }^{34}$ Even if the events of the first and the second Jewish war were dramatic and disruptive, changes in worship and liturgy were gradual, which indicates that no one explanation is behind them. Steven Fine has suggested that elements of prayer and worship are evident in sources from the first century onwards, indicating

\footnotetext{
${ }^{31}$ The Umm el-Qanatir synagogue was tentatively dated by Kohl and Watzinger to the fifth century on stylistic grounds: "Auch die Formen einzelner Bauglieder wie die Kapitelle der Vorhalle und des oberen Umganges lassen eine spätere Entstehungszeit, etwa das V. Jahrh. nach Chr. vermuten. Wie weit der ganze Bau aber einheitlicher Entstehung und die vorgeschlagene Wiederherstellung zutreffend ist, kann erst eine völlige Freilegung lehren.” Heinrich Kohl and Carl Watzinger, Antike Synagogen in Galilaea (Leipzig: Hinrichs, 1916), 127-34; quotation on p. 134. Ilan follows Kohl and Watzinger, Sukenik considered the building Byzantine, and Hüttenmeister and Reeg dated it to the third century, which must be too early. Milson, Art and Architecture, 471. The excavators do not suggest a conclusive dating in the preliminary report, but summarize previous discussions. Dray, Gonen, and Ben David, "The Synagogue of Umm el-Qanatir," 210.

${ }^{32}$ Hachlili, Ancient Synagogues, 125-220.

${ }^{33}$ Hachlili, Ancient Synagogues, 163; Levine, Ancient Synagogue, 160-62.

${ }^{34}$ Scholarly opinions on the significance of the destruction of the Second Temple and the sack of Jerusalem in 70 CE for the development of Judaism in the following centuries vary. See Daniel R. Schwartz, "Introduction: Was 70 CE a Watershed in Jewish History? Three Stages of Modern Scholarship, and a Renewed Effort," in Was 70 CE a Watershed in Jewish History? On Jews and Judaism Before and After the Destruction of the Second Temple, ed. Daniel R. Schwartz and Zeev Weiss, AJEC 78 (Leiden: Brill, 2011), and other articles in the book.
} 
that the sanctity of the synagogue increased over the next centuries. The main source of sanctity derived, in his view, from the sacred Scriptures that were in the synagogue. ${ }^{35}$ The same view is held by Eric Meyers. ${ }^{36}$ Fine finds evidence, e.g., in the works of Philo and Josephus, that already in the Second Temple period synagogues were associated with holiness. He sees the increased holiness of the synagogue building as a result of two factors - the holiness and the cult object status of the Scripture scrolls and the application of temple forms for synagogue worship. ${ }^{37}$ This is how m. Meg. 3:1 and its expression of increasing amounts of holiness can be understood, with the town square as the (low in holiness) starting point, the synagogue building being more sacred, and sacredness finding its culmination in the Torah scrolls inside the synagogue. The chest in which the Torah scrolls are kept is higher in the hierarchy of holiness than the synagogue building, but the cloth wrappers and the rolls exceed the Torah ark in holiness. ${ }^{38}$

Fine's reading of the evidence adds much to our understanding of the changes in synagogue worship. Further, some scholars emphasize the wider context and the impact of Christianity in particular. Lee Levine points to the dominance of Christianity from the fourth century onward, and the challenges as well as the stimulating effect it had on Jewish faith and art. ${ }^{39}$ The flourishing and diversity of Jewish creativity in the literary and material realms are, in his view, to be approached in the wider context of Byzantine Christian society. ${ }^{40}$ Some scholars take a more critical view of the impact of imperial Christianity on Jewish culture. David Milson reads the Torah shrine architecture in relation to church architecture. He reads several architectural features in synagogues as inspired by and adapted from church architecture, particularly altars and low bema areas in churches. His emphasis is on religious rivalry as the force that explains changes such as the introduction of a platform and an apse to

\footnotetext{
${ }^{35}$ Fine, This Holy Place, chs. 1-2. Paula Fredriksen has argued that, for the majority of Jews in antiquity, the most important locations for their religious practice were in fact the synagogue and home. The destruction of the faraway temple, therefore, was not as decisive as often assumed. Paula Fredriksen, Augustine and the Jews: A Christian Defense of Jews and Judaism (New Haven: Yale University Press, 2010), 86-88.

${ }^{36}$ Meyers connects the architectural development with the canonization of Scripture and other developments after 70 CE. Meyers, “The Torah Shrine," 304.

${ }^{37}$ Fine, This Holy Place, 2-3, 25-33.

${ }^{38}$ Fine, This Holy Place, 37-40.

${ }^{39}$ Levine, Ancient Synagogue, 194-98 and 225-31; Levine, "Why Did Jewish Art Flourish," 49-74.

${ }^{40}$ Levine, "Why Did Jewish Art Flourish," 71.
} 
safeguard the Torah scrolls. ${ }^{41}$ The reason behind the similarities are, in his view, to be found in the rivalry and antagonism between Jewish and Christian communities in Palestine. ${ }^{42}$

Questions of Christian influence on Jewish sacred architecture are complex. Church architecture in the Constantinian era was adopted from secular architecture. ${ }^{43}$ Did those planning and building synagogues consciously adapt something they saw in churches? Can the emergence of Torah shrines be interpreted as influence or (counter-)reaction, neither, or both? While it is true that external, intercommunal relations in late antique Palestine were often strained or complicated, do they explain internal changes? We next consider late antique Palestine and questions regarding the relations between Jews and Christians that provide context to changes in synagogue architecture and may be a factor behind the emergence of Torah shrines.

\section{Mapping the Context: Jews and Christians in late antique Palestine}

Jewish and Christian communities of late antique Palestine lived in close proximity to one another, along with the Samaritan and pagan populations. The centuries that followed the Constantinian turn saw Christianity spread from Jerusalem and the surrounding region to new areas so that eventually Christians were found in all regions of Palestine. Galilee had a Christian population that around the Sea of Galilee first concentrated in pilgrim monasteries (Heptapegon-Tabgha, Capernaum, Kursi), but was eventually found in cities, such as Tiberias, Beit Shean/Scythopolis, Sepphoris, and Hippos, and the western Galilee. ${ }^{44}$ Jews and Christians

\footnotetext{
${ }^{41}$ Milson, Art and Architecture, 234-35.

${ }^{42}$ Milson, Art and Architecture, 241-42.

${ }^{43}$ Richard Krautheimer, Early Christian and Byzantine Architecture, 4th ed., rev. by Richard Krautheimer and Slobodan Ćurčić (New Haven: Yale University Press, 1986), 39-43.

${ }^{44}$ For maps that illustrate suggested concentrations of different cultural groups and changes over the centuries, see Claudine Dauphin, La Palestine byzantine: Peuplement et Populations, vol. 2: Texte et Illustrations, BARIS 726 (Oxford: Archeopress, 1998); Mordechai Aviam, Jews, Pagans and Christians in the Galilee: 25 Years of Archaeological Excavations and Surveys: Hellenistic to Byzantine Periods, Land of Galilee 1 (Rochester, NY: University of Rochester Press, 2004), 181-204. Aviam draws a borderline between Christian communities of the western Galilee and the predominantly Jewish eastern Galilee. A thorough discussion of the oldest literary and material evidence for Christian communities in Galilee is Jürgen Zangenberg, "From the Galilean Jesus to Galilean Silence: Earliest Christianity in the Galilee until the Fourth Century CE," in The Rise and Expansion of Christianity in the First Three Centuries of the Common Era, ed. Clare K. Rotschild and Jens Schröter (Tübingen: Mohr Siebeck, 2013), 75-108. Aviam and Ashkenazi argue that the area was important for pilgrimage, despite the lack of literary sources. Aviam and Ashkenazi, "Late Antique Pilgrim Monasteries," 559-73; Mordechai
} 
lived in relative proximity to each other even in remote areas, which means contacts taking place and ties of different kinds binding Jews and Christians together, at least loosely. Although the synagogue on the hilltop of Horvat Kur suggests that this rural community was (primarily) Jewish, it was situated close to two major pilgrim destinations, Tabgha and Capernaum. Even the seemingly remote Umm el-Qanatir was not isolated from either other synagogues or Christian communities. ${ }^{45}$

Interaction can safely be assumed between Jewish and Christian and other inhabitants of the land; what exactly its nature was and what the relations between Jews and Christians were, is not known to us. Archaeological evidence and distribution of remains of churches and synagogues in Galilee appears to indicate certain differences, with more churches found around the Mediterranean coast and western parts of the region, and larger numbers of synagogue remains in the eastern parts. ${ }^{46}$ This is usually interpreted as indicating that in the Upper (eastern) Galilee, Jews and Christians lived in relatively separate areas, whereas the populations of western Lower Galilee and cities were more mixed. ${ }^{47}$

Real life in all likelihood was more complex than what the archaeological evidence indicates. Literary evidence likewise is fragmentary and biased, and it derives from the elites. Christian, but also Jewish, authors of Late Antiquity were, to varying degrees, determined to define the boundaries between the ingroup and outgroups, that is, between what they saw as true worship, doctrine, or way of life (their own perceived orthodoxy) and those who did not belong to that category (either those outside or, often in particular, heretics inside). ${ }^{48}$ Practices

Aviam and Jacob Ashkenazi, "Monasteries, Monks, and Villages in Western Galilee in Late Antiquity," Journal of Late Antiquity 5 (2013): 269-97. On Palestine in general, see Taylor, Christians and Holy Places, 48-85 (on the years 135-324 CE) and Hagith Sivan, Palestine in Late Antiquity (Oxford: Oxford University Press, 2008), $16-50$.

${ }^{45}$ Chaim Ben-David, "Roman-Byzantine Period Settlements Near Gamla," in Gamla III. The Shmarya Gutmann Excavations 1976-1989: Finds and Studies I, ed. Danny Syon. IAA Reports 56 (Jerusalem: IAA, 2014), 239-47; Robin Froumin, "The Christian Settlements on the Golan During the Late Roman-Byzantine Period," ARAM 23 (2011): 645-68; Robert Gregg, "Marking Religious and Ethnic Boundaries: Cases from the Ancient Golan Heights," CH 69 (2000): 519-57.

${ }^{46}$ See n. 45 above.

${ }^{47}$ Aviam, Jews, Pagans and Christians, 202-4; Aviam and Ashkenazi, "Monasteries, Monks, and Villages," 28490; Aviam and Ashkenazi, "Late Antique Pilgrim Monasteries," 569-70; Bar, "Population, Settlement and Economy," 307-20; Taylor, Christians and Holy Places, 84, 295.

${ }^{48}$ Daniel Boyarin, Border Lines: The Partition of Judaeo-Christianity (Philadelphia: University of Pennsylvania Press, 2004), 1-13; Andrew S. Jacobs, Epiphanius of Cyprus: A Cultural Biography of Late Antiquity (Oakland, 
and beliefs of ordinary people are largely undocumented, but probably differed from those of the elites. Occasionally literary evidence suggests interaction that was not on the agenda of religious leaders ${ }^{49}$ What community leaders instruct and elites want is one thing, what common people do and think, another. The fragmentary and biased nature of our sources does not allow a reliable reconstruction of circumstances beyond. Written sources generally seek to influence readers and keep boundaries clear, but this warns us against giving literary sources any universal value. Insights gained from theoretical approaches, the social identity approach in particular, can be used to bring nuance to the meager source materials. ${ }^{50}$

Material culture does not provide clear answers either. It is generally problematic to know much about perceived identities of people through the material culture they left behind. Occasionally evidence is perplexing, as is the case, for example, with lintels found at Farj on the Golan that are decorated with crosses, fish symbols, palm branches, and menorahs. ${ }^{51}$ The symbols have been dated to the latter part of the fourth century and it is difficult to think of any other reading of the symbols than pointing to Jewish and Christian beliefs. By whom and for what purpose remains obscure, although Joan Taylor's suggestion that the inhabitants had originally been Jewish but had become Christians does not emerge as implausible. ${ }^{52}$ Ultimately we do not know if these crosses and menorahs indicate that the people behind the carvings saw no contradiction in being Jewish and Christian, or whether the question is of cultural

CA: University of California Press, 2016), 5-8, 107-8; Andrew S. Jacobs, Remains of the Jews: The Holy Land and Christian Empire in Late Antiquity (Stanford: Stanford University Press, 2003), 23-25. Christian authors did take a more zealous approach, and they did hold the position of power, but a notion of heresy or heretics was not unknown to rabbis. Naomi Koltun-Fromm, "Defining Sacred Boundaries: Jewish-Christian Relations," in A Companion to Late Antiquity, ed. Philip Rousseau (London: Blackwell, 2009), 556-71; Martin Goodman, "The Function of Minim in Early Rabbinic Judaism," in Judaism in the Roman World: Collected Essays (Leiden: Brill, 2014), 163-71.

${ }^{49}$ Fredriksen, Augustine and the Jews, 93-96. John and Barsanuphius of Gaza, Letters 775-776 include a question from a Christian who asks about invitations from Jewish or pagan neighbors to attend their religious festivals. The person is advised to decline, but we do not know if he or others followed the advice. Some of the tales of John Moschus (Meadow 176, Meadow, Nissen 8) may be taken to provide glimpses of Jewish-Christian coexistence that seem sometimes to be based on friendly terms but are prone to violence, certainly on a fictional level.

${ }^{50}$ Hakola, "Galilean Jews and Christians," 161-64.

${ }^{51}$ Claudine Dauphin et al., "Païens, juifs, judéo-Chrétiens, chrétiens et musulmans en Gaulanitide: Les inscriptions de Na'aran, Kafr Naffakh, Farj et Er-Ramthaniyye,” Proche-Orient Chrétien 46 (1996): 305-40.

52 Taylor, Christians and the Holy Places, 37-41. 
recognition or appropriation of some kind.$^{53}$ It may well be that several options are correct, as interpretation of symbols can vary from individual to individual, or over time.

Yet Christianity was undeniably closely connected with political power and agendas from the fourth century onwards. This is visible, for example, in church building and how Christian architecture developed. ${ }^{54}$ Church building and pilgrimage were part of an imperial endeavor that begun in the fourth century and continued until the seventh. It was led by imperial ladies such as Helena, mother of the Emperor Constantine, and Eudocia, wife of Theodosius II. ${ }^{55}$ The rise of Christianity as a state cult and Christian rulers' aim at shaping late antique Palestine into a Christian Holy Land had an impact on the landscape and people of Palestine. It has been proposed that imperial Christianity and the visible Christian presence in the land created a need for the Jewish population to express their identities in more pronounced ways than previously. ${ }^{56}$ The Christianization of Palestine can be analyzed from the viewpoints of imperialism and colonialism. ${ }^{57}$ Concerns for identity and resistance or opposition are, in light of this perspective, one of the forces behind synagogue art and architecture. Some (or many) synagogues of the fourth to the seventh centuries may have been built as a counter-reaction to Christian dominance. ${ }^{58}$

These are persuasive arguments: art can be and is used to express both domination and resistance. Yet any binary model of Jewish resistance and Christian domination can be and should be modified: it is in my view fruitful to be guided by post-colonial theories and to approach cultural coexistence in late antique Palestine as based on negotiation and hybridity. ${ }^{59}$ Art can be a powerful means of expression, and ancient artistic expressions can be analyzed as negotiation. ${ }^{60}$ This is a possible way to analyze the way Torah shrines evolve in the late antique

\footnotetext{
${ }^{53}$ Sivan, Palestine in Late Antiquity, 21-22.

${ }^{54}$ Krautheimer, Early Christian and Byzantine Architecture, 39-43.

${ }^{55}$ Krautheimer, Early Christian and Byzantine Architecture, 59-65, 156-60, 266; R.A. Markus, "How on Earth Could Places Become Holy? Origins of the Christian Idea of Holy Places," JECS 2 (1994): 257-71; Smith, To Take Place, 75-83; Jás Elsner, Imperial Rome and Christian Triumph (Oxford: Oxford University Press, 1998), 232.

${ }^{56}$ Levine, Ancient Synagogue, 225-30.

${ }^{57}$ Seth Schwartz, Imperialism and Jewish Society, 200 B.C.E. to 640 C.E. (Princeton: Princeton University Press, 2001), 179-214. Jacobs, Remains of the Jews, 1-2, 6-16.

${ }^{58}$ Levine, Ancient Synagogue, 225-30; Milson, Art and Architecture, 234-35, 242.

${ }^{59}$ Homi Bhabha, The Location of Culture, 2nd ed. (London: Routledge, 2004), 37-38.

${ }^{60}$ Jane Webster, "Art as Resistance and Negotiation," in Roman Imperialism and Provincial Art, ed. Sarah Scott and Jane Webster (Cambridge: Cambridge University Press, 2003), 24-51.
} 
and Byzantine era, and a way to understand their resemblance to church altars and areas surrounding altars. Sometimes visual and other resemblances to church architecture are very close, as in synagogues that have apses and/or chancel screens, partitions that in synagogues separated the Torah shrine area from the rest of the synagogue interior. Symbols of religious identity were carved on these screens: synagogue chancel screens were decorated with menorahs while chancel screens in churches had crosses in corresponding places. ${ }^{61}$

We next discuss Christian architecture and organization of sacred spaces in order to understand changes in both traditions and to find new aspects in synagogue architecture and the meaning of the Torah shrine in the synagogue.

\section{Hierarchies of sacred spaces and cultic practices}

Changes in late antique Christian attitudes to holiness of buildings and places were as remarkable as in Judaism. Christian perceptions of place/space changed remarkably in the course of the first centuries CE. Our earliest literary sources, New Testament writings, indicate that people and the community were considered holy, whereas buildings where the community gathered were not thought to be so. ${ }^{62}$ Robert Markus has argued that any concept of a sanctity of space was not immediately or easily accepted among Christians. He emphasizes the profound nature of the change that made Palestine a key location due to imperial patronage and pilgrimage. ${ }^{63}$ This is also the time when building of monumental churches begins. ${ }^{64} \mathrm{~A}$ connection between sanctity of meeting places and sanctity of geographical space existed; these changed views, Markus argues, intertwine with concepts of history and notions of sacred time that linked with memories of persecution and martyrs. These memories were to be kept alive.

61 Hachlili, Ancient Synagogues, 186-88, 221-17; Levine, Ancient synagogue, 317-18; Milson, Art and Architecture, chs. 6-7; Lihi Habas, "The bema and chancel screen in synagogues and their origin," in From Dura to Sepphoris: Studies in Jewish Art in Late Antiquity, ed. Lee I. Levine and Zeev Weiss, JRASup 40 (Portsmouth, RI: JRA, 2000), 111-30.

621 Cor 3:10-17 likens the holiness of the community to that of the temple (vaós) without directly commenting on the temple in Jerusalem. Markus, "How on Earth," 264; Ann Marie Yasin, Saints and Church Spaces in the Late Antique Mediterranean: Architecture, Cult, and Community (Cambridge: Cambridge University Press, 2009), 16-21.

${ }^{63}$ Markus, "How on Earth" 257-71.

64 Ann Marie Yasin, "Sacred Space and Visual Art," in The Oxford Handbook of Late Antiquity, ed. Scott Fitzgerald Johnson (Oxford: Oxford University Press, 2012), 935-69; Krautheimer, Early Christian and Byzantine Architecture, 41-43, 59-67. 
Concepts of time and history thus emerge as relevant for understanding spatial changes. ${ }^{65}$ Similar notions concerning time and memory were made regarding synagogues: orientation towards Jerusalem and the prominence of Torah shrines not only emphasize the sacredness of the Scripture, but evoke the temple, lost over two hundred years ago, and its memory. As argued by Joan Branham, the way the memory of the past and the temple were reconstructed in the synagogue lent the synagogue its sacredness. ${ }^{66}$

Torah shrines in synagogues and altars in churches reflect memory, time, and sacredness. They preserve memories of the past and hopes for the future, assemble the present community, accentuate Scriptures as holy, and indicate developed liturgical practices. One way to consider the role of the Torah shrines and altars is to investigate their role in how collective memories were kept and created. Recent scholarly work on collective memory emphasizes the dynamics of the memory, the processual and fluctuating nature of collective or social memory. One of the aspects that is discussed by scholars working with collective memories is the relationship between the official memory as a deliberate construct of the past, and the popular (or individual) memories and their relationship to these dominant narratives. The dynamics of the memory approach stresses the importance of the past for the present, but also the constant processes of shaping memories through multiple discourses. ${ }^{67}$ This perspective reminds us that behind the fragments of the past available to us, we can assume that multiple ways existed to relate with the sacred and the past and structures symbolizing them.

Altars and Torah shrines, further, create and increase hierarchies within the communal space. This suggestion has also been contested: synagogue worship and Jewish faith appear less hierarchical than Byzantine Christianity and its elaborate liturgies. Lihi Habas has suggested that while Christian influence is recognizable in the symbolism of bemata and chancel screens in Byzantine synagogues that have apses, it is doubtful whether we should assume hierarchical functions for synagogue bemata and chancel screens. Habas agrees that

\footnotetext{
${ }^{65}$ Markus, "How on Earth," 265-71.

${ }^{66}$ Branham, "Vicarious Sacrality," 342.

${ }^{67}$ Barbara A. Misztal, Theories of Social Remembering (Maidenhead: Open University Press, 2003), 67-74. Social memory or communal memory perspectives are used in scholarship of early Judaism and Christianity to study ancient sources and communities and how they used their past to shape their present. Since social memory is linked to how communities see and present themselves, the approach comes close to questions of identity. Raimo Hakola, Samuel Byrskog, and Jutta Jokiranta, "Introduction," in Social Memory and Social Identity in the Study of Early Judaism and Early Christianity, ed. Samuel Byrskog, Raimo Hakola, and Jutta Jokiranta, NTOA 116 (Göttingen: Vandenhoeck \& Ruprecht, 2016), 7-11.
} 
such hierarchies are evident in Christian buildings, evidenced by Christian literature, but she reads Jewish literature as not indicating a highly developed sense of hierarchies. ${ }^{68} \mathrm{I}$ agree that Christian liturgy was complex and Christian authors put more time and effort into dividing their opponents and guiding their flocks, and I do not doubt Habas's notion that there is less direct evidence for any tendency to create hierarchies in Rabbinic literature. Yet the Torah shrine does organize the synagogue space, screens do divide architectural space, and, in the literary world, concerns for boundaries have been found in Rabbinic as well as in Christian literature, even if they fall into different genres and were aimed at different audiences. ${ }^{69}$ This is why I argue that a concern for differentiation and hierarchies can be found within the Jewish tradition and the synagogue.

Concerns with hierarchy are reflected and materialize in the architecture of sacred spaces. Sacred space can be analyzed as providing a point of connection between sacred and human, but encounters in the sacred space also happen between members of the community that gathers in that space, including members not present. Ann Marie Yasin builds on the work of Jonathan Z. Smith, and that of other scholars, in her discussion of late antique Christian sacred spaces. She analyzes the ways Christian communities and their different members sought contact with the past and the means by which late antique church spaces negotiate between various functions and needs of different members of the community. ${ }^{70}$ Yasin points out that spaces can be discussed "in terms of social structure, ritual, and performance."71

In a church, the altar is where the sacred hierarchy appears to culminate. It is the focal point of the interior, a place with restricted access where only the highest authorities may enter (priest, bishop, deacons). Prayers and other actions taking place in the altar area, e.g., the eucharist, are ritualized to a high degree. Architectural frameworks of the interior emphasize hierarchy and ritual. They increase the visibility of the altar and direct viewers' attention towards it. ${ }^{72}$ But although altars were the focal points in late antique churches, often they were not the only focal points, as ordinary Christians frequently performed their worship and rituals elsewhere. Already prior to the Constantinian era, commemoration of the dead in cemeteries

\footnotetext{
${ }^{68}$ Lihi Habas, "The bema and chancel screen.” See also Levine, Ancient Synagogue, 600-1.

${ }^{69}$ Koltun-Fromm, "Defining Sacred Boundaries," 565; Daniel Boyarin, Dying for God: Martyrdom and the Making of Christianity and Judaism (Stanford: Stanford University Press, 1999), 23-29; Hakola "Galilean Jews and Christians," 144-45.

70 Yasin, Saints and Church Spaces, 15-34, esp. 26-34, and 44.

${ }^{71}$ Yasin, Saints and Church Spaces, 34.

72 Yasin, Saints and Church Spaces, 151-52.
} 
and activities at martyrs' graves or shrines seem to have been popular lay practices. Written sources show how elites sought to bring these activities under control. ${ }^{73}$

When building of monumental churches in the basilica style began in the fourth century, there emerged, according to Yasin, two trends: one was that altars and saints' memorials were kept separate; the other, that the visual and physical connection between them was strengthened. In the latter case, saints' relics began to be incorporated into altars. Relics were brought into the church space, and Yasin proposes that, when incorporated into the altar, they served to increase its sacrality and that of the church space. ${ }^{74}$ We also see a tendency towards unifying the space, and that is not a spiritual or architectural phenomenon only. Combination of an altar and a relic could have a political element in it, as it ensured increased control of lay activity. Christian sources give ample indications that many lay practices were not favorably received by ecclesiastical elites. There is a clear contradiction between evidence for diverse customs, ideas, and popular practices and bishops' and other elites' claims for authority. ${ }^{75}$

Yasin perceives a reciprocal relationship developing between saints' relics and the altars above them. Relics legitimated the altar, and the altar provided the relics with centrality within the church space. ${ }^{76}$ Although this was a major trend in ancient churches, there was, as already noted, a parallel phenomenon of organizing altars and memorials into separate architectural loci within the same complex. Instead of incorporating relics or a saint's tomb into the altar area, they could also be situated in a separate locus or focal point. Such arrangements of space indicate that multiple spatial patterns or "centers" brought variation to the space and affected the ways people moved into and within the church interior. ${ }^{77}$ Complex processes of negotiation took place regarding uses of the church space by different members of the community. Along

\footnotetext{
${ }^{73}$ Ramsay MacMullen, The Second Church: Popular Christianity A.D. 200-400 (Atlanta: SBL, 2009), 22-32.

${ }^{74}$ Yasin, Saints and Church Spaces, 151-52. There is evidence from the first century of altars containing remains of martyrs; in fact, the New Testament already indicates something like that (Rev 6:9).

${ }^{75}$ Church spaces indicate that elites sought to bring order to Christian communities and control the movement of the laity; MacMullen, The Second Church, 20. See also Maijastina Kahlos, "Meddling in the Middle? Urban Celebrations, Ecclesiastical Leaders and the Roman Emperor in Late Antiquity," in Spaces in Late Antiquity: Cultural, Theological and Archaeological Perspectives, ed. Juliette Day et al. (London: Routledge, 2016), 11-31.

${ }^{76}$ Yasin, Saints and Church Spaces, 151-55.

77 Yasin, Saints and Church Spaces, 156-209. Ann Marie Yasin, "Sight Lines of Sanctity at Late Antique Martyria," in Architecture of the Sacred: Space, Ritual, and Experience from Classical Greece to Byzantium, ed. Bonna D. Wescoat and Robert G. Ousterhout (Cambridge: Cambridge University Press, 2012), 248-80.
} 
with hierarchical tendencies, late antique Christian sacred spaces emerge as diverse and containing spatial distinction.

What do these notions add to our reading of Torah shrines in the synagogues of late antique Palestine? I suggest that, despite notable differences, we gain new insights. We are invited to reflect on the possibility of different practices by different people in or around the same building, to ask how distinctions were perceived between different members of community, to consider whether it is possible to detect any signs or tendencies to control or direct synagogue visitors' attention - or, to ask if Byzantine synagogues and their Torah shrines indicate a more unified concept of space in comparison with churches.

Synagogue worship differed from Christian worship, and there was no such clergy as in Christian communities. Yet that does not mean that no one attempted to seek authority or bring hierarchy/order into the space and community. Large and prominent platforms invite us to reflect on communal hierarchies and leadership positions. They indicate that those building and/or ascending them probably claimed authority and power, either for themselves or for the sacred Scriptures. If human authority is to be emphasized, it is unnecessary to suggest whether it was, for example, the rabbi(s) who claimed authority in synagogues or the local wealthy men: who claimed power could and would vary over time and place. Other elements that indicate hierarchies include donor inscriptions and monumental seats, found, for instance, in the synagogue of Horvat Kur. ${ }^{78}$

Alongside the evidence for the hierarchical arrangement of synagogue space, culminating on the Torah shrine, we should add that most likely only a (small) part of a given community - who held some sort of elite position - gathered in a synagogue. ${ }^{79}$ Not everyone attended. Places and positions accessible to women are difficult to estimate due to lack of evidence. Bernadette Brooten has shown - in response to the assumption of the gender-based division of space in ancient synagogues - that there is no evidence for separation of the sexes in synagogues and no indication of women's galleries either. ${ }^{80}$ Evidence from outside Palestine actually indicates that women were honored as donors and could hold positions of authority as

\footnotetext{
${ }^{78}$ On seats, see Levine, Ancient Synagogue, 323-27; Zangenberg, "Performing the Sacred," 179-83. Hakola in this volume takes a critical stance against reading synagogue donor inscriptions as stemming from different values and sentiments than non-Jewish deeds of euergeteia.

${ }^{79}$ Spigel, Synagogue Seating, 350-55.

${ }^{80}$ Bernadette J. Brooten, Women Leaders in the Ancient Synagogue: Inscriptional Evidence and Background Issues (Chico, CA: Scholars, 1982), 104-23, 139-41.
} 
elders or heads of synagogues. ${ }^{81}$ In his discussion on the question, Chad Spigel argues that the meager evidence, literary and archaeological, should be read as indicating diversity of practices in different communities. ${ }^{82}$ Spigel has elsewhere estimated that while women and minors were not excluded from synagogue worship, it may have been less common for them to participate. ${ }^{83}$

I want to return to the Christian context and veneration of saints that included incorporating relics into altars, and cultic practices around martyrs' tombs. Yasin reads the custom of enclosing relics in altars as a means of relating to the past and concentrating power into a particular architectural location. This invites further thought. There is a connection in the way material objects placed inside a specific structure of the sacred space bring holiness to the surrounding space. The Christian custom of keeping relics in altar areas or connecting structures may be used to reflect on those ancient synagogues that come with particular spaces under their platforms, as is the case, for example, at Umm el-Qanatir and Horvat Kur. We do not know exactly what these spaces were, and why they were built, but they were part of the most focal and important architectural structure of the synagogue interior and could be accessed through a side entrance. They seem to have been intended for valuable objects and were perhaps used as genizot. ${ }^{84}$ The architectural location indicates their significance: carefully preserved artifacts kept within would have established links with the past and may have contained sacredness of their own. Incorporating these spaces and the objects they held into the platform below the Torah shrine indicated their special value, while enhancing the prominence and holiness of the entire structure. The objects hidden within can be thought of as relics of sorts: like a saint's bones inside the altar, material objects kept inside and under the Torah shrine brought and increased its sanctity.

I suggest that these notions made in the context of late antique church spaces can be used to reflect on the uses of space within late antique synagogues. The prominence of Torah shrines has been interpreted as reflecting their increased sanctity, new ways of worship, and

\footnotetext{
${ }^{81}$ Brooten, Women Leaders, 5-55; Bernadette J. Brooten, "Female Leadership in the Ancient Synagogue," in From Dura to Sepphoris: Studies in Jewish Art in Late Antiquity, ed. Lee I. Levine and Zeev Weiss, JRASup 40 (Portsmouth, RI: JRA, 2000), 215-23. Spigel suggests that in some synagogues women may have sat separate from men, possibly in galleries. Spigel, Synagogue Seating, 47-48.

${ }^{82}$ Chad Spigel, "Reconsidering the Question of Separate Seating in Ancient Synagogues,” JJS 63 (2012): 62-83.

${ }^{83}$ Spigel, Synagogue Seating, 354-55.

${ }^{84}$ This is the suggestion of Dray, Gonen, and Ben David, "The Synagogue of Umm el-Qanatir,” 217-18, 228, as regards the small chamber under the platform at Umm el-Qanatir. The synagogue had another, larger space under the western aisle of the synagogue, which they interpret as another, larger geniza.
} 
perceptions of the Torah/Scriptures as sacred. They carried the memory of the temple and the past and they can be read as accentuating the Jewish identity of communities that gathered in synagogues, negotiating with or against Christian imperialism. None of these aspects necessarily excludes another. Further, they may be complemented with notions of hierarchy within space and between the members of the community and their roles.

\section{Conclusions}

This article has approached the emergence of Torah shrines between the fourth and seventh century $\mathrm{CE}$ as a phenomenon that can be analyzed as parallel with how Christian church spaces evolved after the Constantinian era. Archaeological evidence from Palestinian synagogues indicates that new and different types of Torah shrines emerged during the era, resulting in a changed architectural layout of the synagogue interior. Remains of platforms in selected Galilean synagogues and in one synagogue on the Golan were discussed. These platforms in all probability housed the Torah shrine of the synagogue. In each case it was the focal point of the synagogue interior.

Other, less certain, types of evidence are the so-called façade motifs on synagogue mosaic floors. Whether they depict actual architectural structures that stood either in the synagogue in question or elsewhere cannot be settled with certainty, but it is clear that they associate the Torah shrine with the temple by combining imagery and symbols of both. This mingling shows that the Torah shrine, the place of storage for the Scripture scrolls, and the synagogue itself, were conceptualized as sacred space and time.

The sacred and the Scriptures are emphasized, but late antique Torah shrines also organized what was present, that is, space and the people. They divided the space and directed the gaze and thoughts of those in the synagogue. A new hierarchy had been brought into the meeting place of the community: it affected the previous seating arrangement, entrances were transferred or re-positioned, and there were changes in how people moved inside the synagogue. We may assume that restrictions were made regarding access to different areas within the synagogue interior. It is not known who may or may not have ascended the steps leading to the Torah shrine, entered the interior spaces beneath, and so forth. In some cases, the interior space can be assumed to have complemented the hierarchy of the sacred, perhaps interrelating with the Christian custom of placing relics under altars.

The relatedness of Christian and Jewish art and architecture has been acknowledged by many scholars previously. Remains of Torah shrines and surrounding structures, such as chancel screens and apses, indicate a relatively close resemblance to church architecture. The 
Christianity of the era was a political force closely tied to imperial power. It can be perceived as a negative force that brought about threat as well as domination to the Jewish inhabitants of Palestine, and called for their resistance and counter-reaction. Christian leaders sought to control not only others, but likewise many of their own were controlled and marginalized: the laity was criticized for its erroneous ways, heretics condemned, women brought to submission.

Despite the dark tones associated with Christianity, any model that builds on the dichotomy of domination vs. resistance is in my view inadequate. Drawing from post-colonial studies, we can suggest that Jewish responses to Christianity should be seen as negotiations. This approach is in place when we inquire into the architecture of Torah shrines and the organization of the synagogue space in Late Antiquity. The Torah shrine does not stand in opposition to what stood in churches, but as expression of identity. We see a resemblance to altars and to the concept of the church as sacred space, equally novel developments in their context. Both Jewish and Christian communities begin, around the start of the Constantinian era, to seek new ways to organize the community and the sacred, outside and inside, in time and space.

\section{Cited Literature}

Avi-Yonah, Michael. "Synagogue Architecture in the Classical Period." Pages 155-90 in Jewish Art: An Illustrated History. Edited by Cecil Roth. London: W. H. Allen, 1961.

Aviam, Mordechai. Jews, Pagans and Christians in the Galilee: 25 Years of Archaeological Excavations and Surveys Hellenistic to Byzantine Periods. Land of Galilee 1. Rochester, NY: University of Rochester Press, 2004.

Aviam, Mordechai, and Jacob Ashkenazi. "Late Antique Pilgrim Monasteries in Galilean Loca Sancta." LASBF 64 (2014): 559-73.

Aviam, Mordechai, and Jacob Ashkenazi. "Monasteries, Monks, and Villages in Western Galilee in Late Antiquity.” Journal of Late Antiquity 5 (2013): 269-97.

Bar, Doron. "Population, Settlement and Economy in Late Roman and Byzantine Palestine (70-641 AD)." BSOAS 3 (2004): 307-20.

Ben-David, Chaim. "Roman-Byzantine Period Settlements Near Gamla." Pages 239-47 in Gamla III. The Shmarya Gutmann Excavations 1976-1989: Finds and Studies I. Edited by Danny Syon. IAA Reports 56. Jerusalem: IAA, 2014.

Bhabha, Homi. The Location of Culture. 2nd ed. London: Routledge, 2004.

Boyarin, Daniel. Border Lines: The Partition of Judaeo-Christianity. Philadelphia: University of Pennsylvania Press, 2004. 
Boyarin, Daniel. Dying for God: Martyrdom and the Making of Christianity and Judaism. Stanford: Stanford University Press, 1999.

Branham, Joan. "Vicarious Sacrality: Temple Space in Ancient Synagogues." Pages 319-349 in vol. 2 of Ancient Synagogues: Historical Analysis and Archaeological Discovery. Edited by Dan Urman and Paul V.M. Flesher. StPB 47. Leiden: Brill, 1995.

Brooten, Bernadette J. "Female Leadership in the Ancient Synagogue." Pages 215-23 in From Dura to Sepphoris: Studies in Jewish Art and Society in Late Antiquity. Edited by Lee I. Levine and Zeev Weiss. JRASup 40. Portsmouth, RI: JRA, 2000.

Brooten, Bernadette J. Women Leaders in the Ancient Synagogue: Inscriptional Evidence and Background Issues. BJS 36. Chico, CA: Scholars, 1982.

Dauphin, Claudine. La Palestine byzantine: Peuplement et Populations, Vol. 2: Texte et Illustrations. BARIS 726. Oxford: Archeopress, 1998.

Dauphin, Claudine, Sebastian Brock, Robert C. Cregg, and A.F.L. Beeston. "Païens, juifs, judéo-Chrétiens, chrétiens et musulmans en Gaulanitide: Les inskriptions de Na'aran, Kafr Naffakh, Farj et Er-Ramthaniyye.” Proche-Orient Chrétien 46 (1996): 305-40.

Dauphin, Claudine M., and Jeremy J. Schonfield. "Settlements of the Roman and Byzantine Periods on the Golan Heights: Preliminary Report on Three Seasons of Survey (19791981).” IEJ 33 (1983): 189-206.

Deines, Roland. "God's Revelation Through Torah, Creation, and History: Interpreting the Zodiac Mosaics in Synagogues." Pages 155-186 in Jewish Art in Its Late Ancient Context. Edited by Uzi Leibner and Catherine Hezser. TSAJ 163. Tübingen: Mohr Siebeck, 2016.

Dothan, Moshe. Hammath Tiberias, Vol. 1: Early Synagogues and the Hellenistic and Roman Remains. Jerusalem: Israel Exploration Society, 1983.

Dray, Yehoshua, Ilana Gonen and Chaim Ben David. "The Synagogue of Umm el-Qanatir: Preliminary Report.” IEJ 67 (2017): 209-31.

Elsner, Jás. Imperial Rome and Christian Triumph. Oxford: Oxford University Press, 1998.

Fine, Steven. This Holy Place: On the Sanctity of the Synagogue during the Greco-Roman Period. Christianity and Judaism in Antiquity 11. Notre Dame, IN: University of Notre Dame Press, 1997.

Fredriksen, Paula. Augustine and the Jews: Christian Defence of Jews and Judaism. Paperback ed. New Haven: Yale University Press, 2010.

Froumin, Robin. "The Christian Settlements on the Golan During the Late Roman-Byzantine Period." ARAM 23 (2011): 645-68. 
Gelfand, Laura D. 'Sense and Simulacra: Manipulation of the sense in medieval 'copies' of Jerusalem.” Postmedieval: a journal of medieval cultural studies 3 (2012): 407-22.

Goodman, Martin. “The Function of Minim in Early Rabbinic Judaism.” Pages 163-173 in Judaism in the Roman World: Collected Essays. Leiden: Brill, 2014.

Gregg, Robert. "Marking Religious and Ethnic Boundaries: Cases from the Ancient Golan Heights." CH 69 (2000): 519-57.

Griffth-Jones, Robin. "Public, Private and Political Devotion: Re-presenting the Sepulchre." Pages 17-47 in Tomb and Temple: Re-imagining the Sacred Buildings of Jerusalem. Edited by Robin Griffth-Jones and Eric Fernie. Woodbridge: The Boydell Press, 2018.

Habas, Lihi. "The bema and chancel screen in synagogues and their origin." Pages 111-30 in From Dura to Sepphoris: Studies in Jewish Art and Society in Late Antiquity. Edited by Lee I. Levine and Zeev Weiss. JRASup 40. Portsmouth, RI: JRA, 2000.

Hachlili, Rachel. Ancient Synagogues-Archaeology and Art: New Discoveries and Current Research. HdO 105. Leiden: Brill, 2013.

Hakola, Raimo. "Galilean Jews and Christians in Context: Spaces Shared and Contested in the Eastern Galilee in Late Antiquity." Pages 141-65 in Spaces in Late Antiquity: Cultural, Theological and Archaeological Perspectives. Edited by Juliette Day, Raimo Hakola, Maijastina Kahlos, and Ulla Tervahauta. London: Routledge, 2016.

Hakola, Raimo, Samuel Byrskog, and Jutta Jokiranta. "Introduction.” Pages 7-19 in Social Memory and Sociel Identity in the Study of Early Judaism and Early Christianity. Edited by Samuel Byrskog, Raimo Hakola, and Jutta Jokiranta. NTOA 116. Göttingen: Vandenhoeck \& Ruprecht, 2016, 7-11.

Jacobs, Andrew S. Epiphanius of Cyprus: A Cultural Biography of Late Antiquity. Oakland, CA: University of California Press, 2016.

Jacobs, Andrew S. Remains of the Jews: The Holy Land and Christian Empire in Late Antiquity. Stanford: Stanford University Press, 2003.

Kahlos, Maijastina. "Meddling in the Middle? Urban Celebrations, Ecclesiastical Leaders and the Roman Emperor in Late Antiquity." Pages 11-31 in Spaces in Late Antiquity: Cultural, Theological and Archaeological Perspectives. Edited by Juliette Day, Raimo Hakola, Maijastina Kahlos, and Ulla Tervahauta. London: Routledge, 2016.

Kinneret College. "The Bornblum Eretz Israel Synagogues Website." 2016. http://synagogues.kinneret.ac.il/.

Kohl, Heinrich, and Carl Watzinger. Antike Synagogen in Galilaea. Leipzig: Hinrichs, 1916. 
Koltun-Fromm, Naomi. "Defining Sacred Boundaries: Jewish-Christian Relations." Pages 556-71 in A Companion to Late Antiquity. Edited by Philip Rousseau. London: Blackwell, 2009.

Krautheimer, Richard. Early Christian and Byzantine Architecture. 4th ed. Revised by Richard Krautheimer and Slobodan Ćurčić. Pelican History of Art. New: Yale University Press, 1986.

Krautheimer, Richard. "Iconography of Medieval Architecture." Journal of the Warburg and Courtauld Institutes 5 (1942): 1-33.

Kühnel, Bianca. "The Synagogue Floor Mosaic in Sepphoris: between Paganism and Christianity." Pages 31-43 in From Dura to Sepphoris: Studies in Jewish Art in Late Antiquity. Edited by Lee I. Levine and Zeev Weiss. JRASup 40. Portsmouth, RI: JRA, 2000.

Levine, Lee I. The Ancient Synagogue: The First Thousand Years. New Haven: Yale University Press, 2000.

Levine, Lee I. "Why Did Jewish Art Flourish in Late Antiquity?" Pages 49-74 in Jewish Art in Its Late Ancient Context. Edited by Uzi Leibner and Catherine Hezser. TSAJ 163. Tübingen: Mohr Siebeck, 2016.

MacMullen, Ramsay. The Second Church: Popular Christianity A.D. 200-400. Atlanta: SBL, 2009.

Markus, R.A. "How on Earth Could Places Become Holy? Origins of the Christian Idea of the Holy Places.” JECS 2 (1994): 257-71.

Meyers, Eric M. "The Torah Shrine in the Ancient Synagogue: Another Look at the Evidence." JSQ 4 (1997): 303-38.

Milson, David. Art and Architecture of the Synagogue in Late Antique Palestine: In the Shadow of the Church. AJEC 65. Leiden: Brill, 2007.

Misztal, Barbara A. Theories of Social Remembering. Maidenhead: Open University Press, 2003.

Ousterhout, Robert. "The Temple, the Sepulchre, and the Martyrion of the Savior." Gesta 29 (1990): 44-53.

Peleg-Barkat, Orit. "Interpreting the Uninterpreted: Art as a Means of Expressing Identity in Early Roman Judea." Pages 27-48 in Jewish Art in Its Late Ancient Context. Edited by Uzi Leibner and Catherine Hezser. TSAJ 163. Tübingen: Mohr Siebeck, 2016.

Roth, Cecil. "Jewish Antecedents of Christian Art." Journal of the Warburg and Courtauld Institutes 16 (1953): 24-44. 
Schwartz, Daniel R. "Introduction: Was 70 CE a Watershed in Jewish History? Three Stages of Modern Scholarship, and a Renewed Effort." Pages 1-19 in Was 70 CE a Watershed in Jewish History? On Jews and Judaism Before and After the Destruction of the Second Temple. Edited by Daniel R. Schwartz and Zeev Weiss. AJEC 78. Leiden: Brill, 2011.

Schwartz, Seth. Imperialism and Jewish Society, 200 B.C.E. to 640 C.E. Princeton: Princeton University Press, 2001.

Sivan, Hagith. Palestine in Late Antiquity. Oxford: Oxford University Press, 2008.

Smith, Jonathan Z. To Take Place: Toward Theory in Ritual. Chicago: University of Chicago Press, 1987.

Spigel, Chad. Ancient Synagogue Seating Capacities: Methodology, Analysis and Limits. TSAJ 149. Tübingen: Mohr Siebeck, 2012.

Spigel, Chad. "Reconsidering the Question of Separate Seating in Ancient Synagogues." JJS 63 (2012): 62-83.

Taylor, Joan E. Christians and the Holy Places: The Myth of Jewish-Christian Origins. Oxford: Clarendon, 1993.

Trolle, Stephen, and Peter Pentz. "Den hellige Grav i Jerusalem." Nationalmuseets Arbejdsmark (1983): 97-112.

Webster, Jane. "Art as Resistance and Negotiation.” Pages 24-51 in Roman Imperialism and Provincial Art. Edited by Sarah Scott and Jane Webster. Cambridge: Cambridge University Press, 2003.

Weiss, Zeev. "Decorating the Sacred Realm: Biblical Depictions in Synagogues and Churches of Ancient Palestine." Pages 121-37 in Jewish Art in Its Late Ancient Context. Edited by Uzi Leibner and Catherine Hezser. TSAJ 163. Tübingen: Mohr Siebeck, 2016.

Weiss, Zeev. "The Sepphoris synagogue mosaic and the rôle of Talmudic literature in its iconographical study." Pages 15-30 in From Dura to Sepphoris: Studies in Jewish Art in Late Antiquity. Edited by Lee I. Levine and Zeev Weiss. JRASup 40. Portsmouth, RI: JRA, 2000.

Wishnitzer-Bernstein, Rachel. "Jewish Pictorial Art in the Classical Period." Pages 191-224 in Jewish Art: An Illustrated History. Edited by Cecil Roth. London: W. H. Allen, 1961. Yasin, Ann Marie. "Sacred Space and Visual Art." Pages 935-69 in The Oxford Handbook of Late Antiquity. Edited by Scott Fitzgerald Johnson. Oxford: Oxford University Press, 2012.

Yasin, Ann Marie. Saints and Church Spaces in the Late Antique Mediterranean: Architecture, Cult, and Community. Cambridge: Cambridge University Press, 2009. 
Yasin, Ann Marie. "Sight Lines of Sanctity at Late Antique Martyria." Pages 248-80 in Architecture of the Sacred: Space, Ritual, and Experience from Classical Greece to Byzantium. Edited by Bonna D. Wescoat and Robert G. Ousterhout. Cambridge: Cambridge University Press, 2012.

Zangenberg, Jürgen K. “A Basalt Stone Table from the Byzantine Synagogue at Horvat Kur, Galilee: Publication and Preliminary Interpretation." Pages 61-78 in Arise, Walk Through the Land: Studies in the Archaeology and History of the Land of Israel in Memory of Yizhar Hirschfeld on the Tenth Anniversary of his Demise. Edited by Joseph Patrich, Orit Peleg-Barkat, and Erez Ben-Yosef. Jerusalem: Israel Exploration Society, 2016.

Zangenberg, Jürgen K. "From the Galilean Jesus to Galilean Silence: Earliest Christianity in the Galilee until the Fourth Century CE." Pages 75-108 in The Rise and Expansion of Christianity in the First Three Centuries of the Common Era. Edited by Clare K. Rotschild and Jens Schröter. Tübingen: Mohr Siebeck, 2013.

Zangenberg, Jürgen K. "Performing the Sacred in a Community Building: Observations from the 2010-2015 Kinneret Regional Project Excavations in the Byzantine Synagogue of Horvat Kur (Galilee)." Pages 166-89 in Spaces in Late Antiquity: Cultural, Theological and Archaeological Perspectives. Edited by Juliette Day, Raimo Hakola, Maijastina Kahlos, and Ulla Tervahauta. London: Routledge, 2016.

Zangenberg, Jürgen K. "Will the Real Women Please Sit Down: Interior Space, Seating Arrangements, and Female Presence in the Byzantine Synagogue of Horvat Kur in Galilee.” Pages 91-118 in Gender and Social Norms in Ancient Israel, Early Judaism and Christianity: Texts and Material Culture in Eastern Mediterranean Cultures. Edited by Michael Bauks, Katherina Galor, and Judith Hartenstein. JAJSup 28. Göttingen: Vandenhoeck \& Ruprecht, 2019.

Zangenberg, Jürgen K., Stefan Münger, Raimo Hakola and Byron R. McCane. "The Kinneret Regional Project Excavations of a Byzantine Synagogue at Horvat Kur, Galilee, 20102013: A Preliminary Report," HBAI 2 (2013): 557-76.

Zangenberg, Jürgen K. et al. "Horbat Kur, Kinneret Regional Project - 2012, 2013,” Hadashot Arkheologiyot-Excavations and Surveys in Israel 128 (2016): http://www.hadashotesi.org.il/Report_Detail_Eng.aspx?id=24903. 